\title{
Oak Ridge National Laboratory Melton Valley Storage Tanks Waste Filtration Process Evaluation
}

by

B. W. Walker

Westinghouse Savannah River Company

Savannah River Site

Aiken, South Carolina 29808

D. McCabe

This paper was prepared in connection with work done under the above contract number with the U.S. Department of Energy. By acceptance of this paper, the publisher and/or recipient acknowledges the U. S. Government's right to retain a nonexclusive, royalty-free license in and to any copyright covering this paper, along with the right to reproduce and to authorize others to reproduce all or part of the copyrighted paper. 


\section{DISCLAIMER}

This report was prepared as an account of work sponsored by an agency of the United States Government. Neither the United States Government nor any agency thereof, nor any of their employees, makes any warranty, express or implied, or assumes any legal liability or responsibility for the accuracy, completeness, or usefulness of any information, apparatus, product, or process disclosed, or represents that its use would not infringe privately owned rights. Reference herein to any specific commercial product, process, or service by trade name, trademark, manufacturer, or otherwise does not necessarily constitute or imply its endorsement, recommendation, or favoring by the United States Government or any agency thereof. The views and opinions of authors expressed herein do not necessarily state or reflect those of the United States Government or any agency thereof.

This report has been reproduced directly from the best available copy.

Available to DOE and DOE contractors from the Office of Scientific and Technical Information, P. O. Box 62, Oak Ridge, TN 37831; prices available from (423) 576-8401.

Available to the public from the National Technical Information Service, U. S. Department of Commerce, 5285. Port Royal Road, Springfield, VA 22161. 


\section{DISCLAIMER}

Portions of this document may be illegible in electronic image products. Images are produced from the best available original document. 
WSRC-TR-97-00354

Rev. 1

Distribution

W.B. Van Pelt, 679-T

W.L. Tamosaitis, 773-A

R.A. Peterson, 773-A

T.E. Kent, ORNL

Ben Lewis, ORNL

J. Wilson, ORNL

C.P. McGinnis, ORNL

C.A. Nash, 773-42A 
To: Distribution

From: B. W. Walker

Revision of Document WSRC-TR-00354

Attached is revision 1 of Document WSRC-TR-00354. In this revision values for the DP coordinate in Figure 5 on page 13 have been corrected. 
WSRC-TR-97-00354

Revision 1

Keywords: Cross-flow

Filtration

Retention: Permanent

\section{Oak Ridge National Laboratory Melton Valley Storage Tanks Waste} Filtration Process Evaluation (U)

September 30, 1997

B.W. Walker, $773-42 \mathrm{~A}$

D.J. McCabe, $773-43 \mathrm{~A}$

Savannah River Technology Center Westinghouse Savannah River Company Samued Anif 5-14-98 $\frac{\text { Samuel D. Fink, Mgr }}{\text { Authorized Reviewing Official }}$ Aiken, SC 29808

Prepared for the Department of Energy

Office of Science and Technology

Tanks Focus Area Program

Technical Task Plan SR16-WT-41

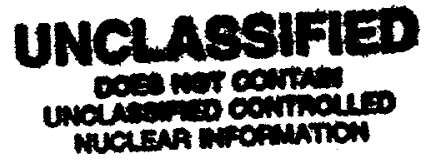




\section{Summary}

Cross-flow filtration is being evaluated as a pretreatment in the proposed treatment processes for aqueous high level radioactive wastes at Oak Ridge National Laboratory (ORNL) to separate insoluble solids from aqueous waste from the Melton Valley Storage Tanks (MVST).

Filter studies were conducted on simulants with and without Bentonite clay to determine what effect it has on filtration characteristics. A simulant was prepared from a formulation by ORNL personnel and filter studies were conducted with 0.5 micron crossflow sintered metal Mott filters. The following deductions were drawn from the experimental results:

- Cross-flow filtration was proven to be an effective solid-liquid separation technology with both of the simulants.

- Filter cleaning after the filtration studies was possible using $2 \mathrm{wt} \% \mathrm{HNO}_{3}$ but not with 2 wt $\% \mathrm{NaOH}$ or 2 wt $\%$ oxalic acid.

For the simulant without Bentonite clay the following was observed:

- Filtrate production is not controlled by the transmembrane differential pressure.

- Filtrate production is not controlled by axial velocity of the slurry through the filter.

- Filtrate production does not decrease significantly with time indicating that filter fouling is not occurring during the filtration.

For the simulant with Bentonite clay the following was observed:

- Filtrate production is controlled by the transmembrane differential pressure.

- Filtrate production is controlled by axial velocity of the slurry through the filter.

- Filtrate production does not decrease significantly with time indicating that filter fouling is not occurring during the operation. 


\section{Introduction}

The purpose of this filter study was to evaluate cross-flow filtration as effective solidliquid separation technology for treating Oak Ridge National Laboratory wastes, outline operating conditions for equipment, examine the expected filter flow rates, and determine proper cleaning.

The Gunite Tanks at the Oak Ridge National Laboratory contain heels which are a mixture of sludge, wash water, and bentonite clay.' The tanks are to be cleaned out with a variety of flushing techniques and the dilute mixture transferred to another storage tank. One proposal is to transfer this mixture into existing Melton Valley Storage Tanks (MVST), which already contain a large amount of sludge and supernate. The mixed aqueous phase will then be transferred to new MVST, which are prohibited from containing insoluble solids. To separate the solid from the liquid and thereby prevent solids transfer into the new MVST, a technique is needed that can cleanly separate the sludge and bentonite clay from the supernate. One proposed method for solid liquid separation is cross-flow filtration. Cross-flow filtration has been used at the Savannah River and West Valley sites for treatment of tank waste, and is being tested for applicability at other sites. The performance of cross-flow filters with sludge has been tested, but the impact of sludge combined with bentonite clay has not. The objective of this test was to evaluate the feasibility of using cross-flow filters to perform the solid liquid separation required for the mixture of Gunite and MVST tank wastes.

\section{Solid/Liquid Separation Method Selection}

Although numerous solid/liquid separation technologies are commercially available, few are adaptable to high radiation fields.' However, the In-Tank Precipitation process at the Savannah River Site uses cross-flow filters made of seamless, sintered stainless steel. The filter elements are welded to the housing and contain no polymeric components. This design limits maintenance requirements to chemical cleaning and pump maintenance, which can be done remotely. Cross-flow filters can concentrate slurries to relatively high weight loadings while maintaining filtrate production rates.

\section{Testing Strategy}

Laboratory filtration equipment is adequate for scoping activities identifying significant impacts to filter performance. Filtrate fluxes are generally higher with laboratory scale equipment than observed at production scale. Higher fluxes on small-scale equipment have been attributed to more effective backpulsing and chemical cleaning. In addition. end effects cause increased turbulence that impacts the boundary layer thickness. On short filter tubes the high turbulence area is a significant fraction of the length and thereby contributes to higher flux rates. 
The accuracy and confidence of results obtained by use of simulated versus actual waste depend on several factors. Because these factors are not fully understood for filtration of sludge, comparisons are needed between simulants and actual waste. Detailed studies of the physical and chemical characteristics of the wastes are needed to develop accurate simulants, and these data are not available. Radioactive waste filter tests are needed for final verification of equipment selection and sizing.

The bentonite clay that was added as a suspension agent to the Gunite tanks was "thixogel" from Georgia Kaolin Company. The bentonite plant was purchased by Black Hills Bentonite Company. According to the vendor, the "Black Hills Bond" is comparable to thixogel.

\section{Experimental}

\section{Simulant Preparation}

Simulants were developed at Oak Ridge National Laboratory (ORNL) ${ }^{2}$ for testing of the cross-flow filtration processes. Filtration was conducted first on a simulant without clay and then on a simulant with Black Hills Bentonite Clay added.

The formulation for simulant without Bentonite clay was prepared as follows:

Step 1 - Add 6.6 grams of $\mathrm{Fe}\left(\mathrm{NO}_{3}\right)_{3} \cdot 9 \mathrm{H}_{2} \mathrm{O}$ to $10 \mathrm{mls}$ of deionized $\mathrm{H}_{2} \mathrm{O}$ with agitation to form Solution 1.

Step 2 - Add $77.11 \mathrm{~g}$ of $\mathrm{NaOH}$ to $200 \mathrm{mls}$ of deionized $\mathrm{H}_{2} \mathrm{O}$ with agitation to form Solution 2.

Step 3 - Add $221.52 \mathrm{~g}$ of $\mathrm{Ca}\left(\mathrm{NO}_{3}\right)_{2} .4 \mathrm{H} 2 \mathrm{O}$ to $100 \mathrm{mls}$ of deionized $\mathrm{H}_{2} \mathrm{O}$ with agitation to form Solution 3 .

Step 4 - Add Solution 1 to Solution 2 slowly with continuous mixing to form

Solution 4

Step 5 - Add Solution 3 to Solution 4 to form Solution 5.

Step 6 - Add $8.2 \mathrm{~g}$ of $\mathrm{NaAlO}_{2}$ to Solution 5 to form Solution 6.

Step 7 - Add $21.2 \mathrm{~g}$ of $\mathrm{Na}_{2} \mathrm{CO}_{3}, 4.71 \mathrm{~g}$ of $\mathrm{NaCl}, 48.06 \mathrm{~g} \mathrm{KNO}_{3}$, and $137.1 \mathrm{~g} \mathrm{NaNO}_{3}$ to $150 \mathrm{mls}$ of deionized $\mathrm{H}_{2} \mathrm{O}$ to form Solution 7.

Step 8 - Add Solution 7 to Solution 6 to form Solution 8.

Step 9 - Add $195.82 \mathrm{~g} \mathrm{CaCO}_{3}$ and $42.71 \mathrm{~g}$ of $\mathrm{Mg}(\mathrm{OH})_{2}$ to Solution 8 to form Solution 9. Step 10 - Add $1.52 \mathrm{~g} \mathrm{NaOH}$ to $20 \mathrm{ml} \mathrm{H}_{2} \mathrm{O}$ to form Solution 10 .

Step 11 - Add $8.45 \mathrm{~g} \mathrm{H}_{2} \mathrm{SiO}_{3}$ to Solution 10 to form Solution 11 .

Step 12 - Add Solution 11 to Solution 9 to form final slurry mixture.

The final slurry was agitated for 24 hours to obtain a homogeneous mixture and to encourage any chemical reactions to take place. The total volume of this solution after mixing was $900 \mathrm{mls}$. 
This formulation was scaled up for a 20 liter batch of slurry. The weight $\%$ solids of the initial slurry was determined to be $6.8 \mathrm{wt} \%$ insoluble solids. Filtrate was removed $(6800$ $\mathrm{mls}$ ) to obtain a $11.33 \mathrm{wt} \%$ insoluble solids slurry for the first filtration test without the Bentonite clay.

For the second filtration test the slurry with clay was prepared by adding $2000 \mathrm{mls}$ of filtrate back to the slurry which yielded $9.67 \mathrm{wt} \%$ insoluble solids. Bentonite clay $(200.4$ grams) was then added to the slurry giving a final wt \% insoluble solids of 10.62 which was used for the second filtration study.

\section{Cross-flow Filter Operating Conditions}

Cross-flow filtration experiments were performed with each of these simulants using the Parallel Rheology Experimental Filter (PREF) shown in Sketch 1. The simulant was recirculated through the filters at room temperature and filtration performance data collected.

Each test involved measuring the filtrate flux under a variety of conditions. The two independent variables for these tests were the transmembrane pressure drop and axial velocity. Transmembrane pressure drop is defined as the sum of slurry pressure entering and exiting the filter divided by 2 minus the pressure of the filtrate as it leaves the filter. Axial velocity is defined as the speed that the slurry is moving inside the filter. The conditions for the test are listed in Table 1. The test settings of variables were determined using a statistical model to cover low, high, and intermediate points of the variable ranges. The order of the variable settings was also varied to minimize experimental errors associated with taking data points at the same time in the same range. A backpulse was performed following each change in the test parameters. Measurements were taken at each test condition for a period of 1 hour. Data points were manually collected every 10 minutes of operation. In addition a data acquisition system recorded process parameters every minute in the event that more detail was needed. 
Following the completion of each test, a statistical analysis determined the dependence of filtrate flux for those test conditions as a function of transmembrane pressure drop and axial velocity. An additional analysis was performed to determine the dependence of filter performance on time (as an indication of filter fouling).

\section{Table 1 - Test settings}

$\begin{array}{lll}\begin{array}{l}\text { Number of runs at } \\ \text { each condition set }\end{array} & \begin{array}{l}\text { Pressure } \\ \text { (psi) }\end{array} & \begin{array}{l}\text { Velocity } \\ (\mathrm{f} / \mathrm{s})\end{array} \\ 2 & 20 & 2.6 \\ 4 & 25 & 3.6 \\ 4 & 25 & 1.6 \\ 2 & 20 & 2.6 \\ 2 & 15 & 1.6 \\ 2 & 15 & 3.6 \\ 2 & 20 & 2.6\end{array}$

\section{Equipment Description}

The cross-flow filters were fabricated by Mott Metallurgical Corporation of Farmington, Conn. and are seamless tubes. Mott filters were 0.0625 inches thick and 0.5 inch inner diameter. A progressive cavity positive displacement pump manufactured by Moyno Industrial Products of Springfield, Ohio provided slurry flow during the filtration study. The Parallel Rheological Experimental filter apparatus and associated equipment used in the filtration study are shown in Sketch 1. 
Sketch 1.

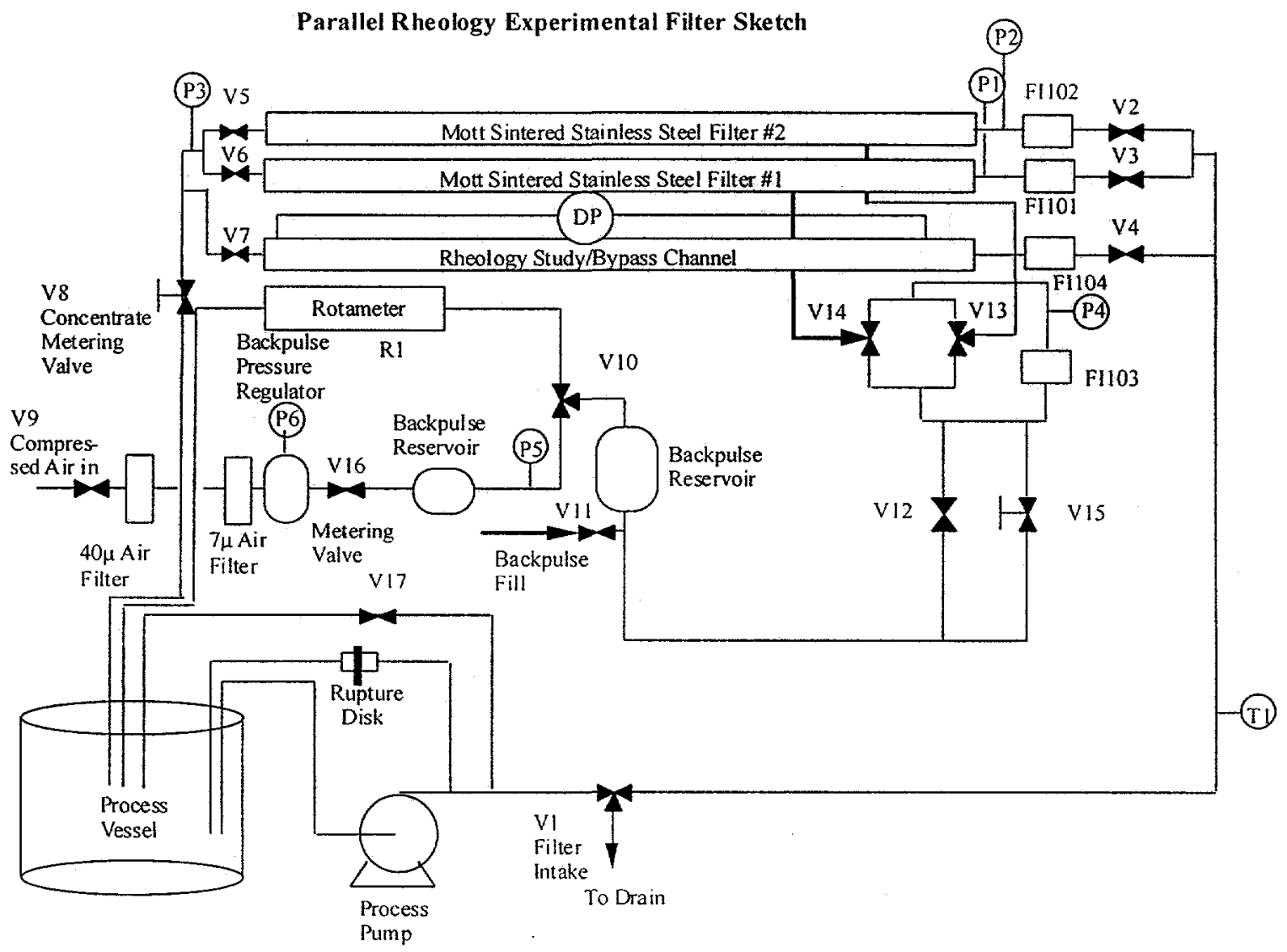




\section{Filtration Mechanism}

In cross-flow filtration the fluid to be filtered flows in parallel to the membrane surface and generates shearing forces and/or turbulence across the filter medium which influences formation of a filter cake.

Cross-flow filtration can be separated into two areas of operation. ${ }^{3}$ In the first area of operation, the axial velocity is sufficient to remove any solids from the surface of the filter. Thus, there is not an accumulation of filter cake on the surface of the filter and any decrease in filter performance is attributed to the deposition of solids within the filter pores. This area of operation is usually associated with dilute feed streams, high axial velocities and low pressure drops. Under these conditions, increasing the axial velocity of the feed stream concentration will have little impact on filtrate production rates. However, increases in transmembrane pressure drop will produce significant increases in filtrate flow rates. For the simulant without Bentonite clay the filtrate production does not increase significantly with increasing transmembrane pressure drop indicating that deposition of solids is not occurring in the filter pores. For the simulant with Bentonite clay the filtrate production does increase significantly with increasing transmembrane pressure drop indicating that deposition of solids is occurring in the filter pores.

In the second area of operation, normally when more concentrated feed streams are employed, a higher axial velocity is needed to keep the surface of the filter free of deposited solids. If the axial velocity is not sufficient, a cake of solids will deposit on the surface of the filter. Under these conditions, an increase in the axial velocity will increase the rate of transport of solids from the surface of the filter, and thus decrease the thickness of the filter cake, producing an increase in filter performance. The surface filter cake will cause a decrease in filter performance when an excessive thickness of filter cake is deposited. However an increase in pressure without increasing the axial velocity will only produce a thicker or more compressed cake and will not yield any further increase in filter performance. For the simulant without Bentonite clay the filtrate production does not increase significantly with increasing axial velocity indicating that a filter cake is not forming on the filter surface. The filtrate production of the simulant with Bentonite clay does increase significantly with increasing axial velocity indicating that a filter cake is forming on the filter surface. 


\section{Filtration Results}

A filtrate flux range of 0.01 to $0.06 \mathrm{gpm} / \mathrm{f}^{2}$ was obtained during the two filtration studies for the tests with and without bentonite clay.

If a filter cake does not form on the surface of the filter, increases in axial velocity will not decrease the depth of a filter cake and thus improve filtration performance. Figure 1 contains a plot of the filtrate flux $\left(\mathrm{gpm} / \mathrm{f}^{2}\right)$ for the simulant without bentonite as a function of axial velocity. Linear regression of this data indicates that filtrate flux does not increase statistically in response to increases in axial velocity and therefore there is no surface filter cake developed. Although the data appears to have a large variance it should be noted that the transmembrane pressure is also being varied during these statistically-designed experiments. Note that these predictions are valid only over the range of operating conditions outlined in Table 1 in the Experimental section.

Figure 1. Filtrate Flux vs. Axial Velocity without Bentonite

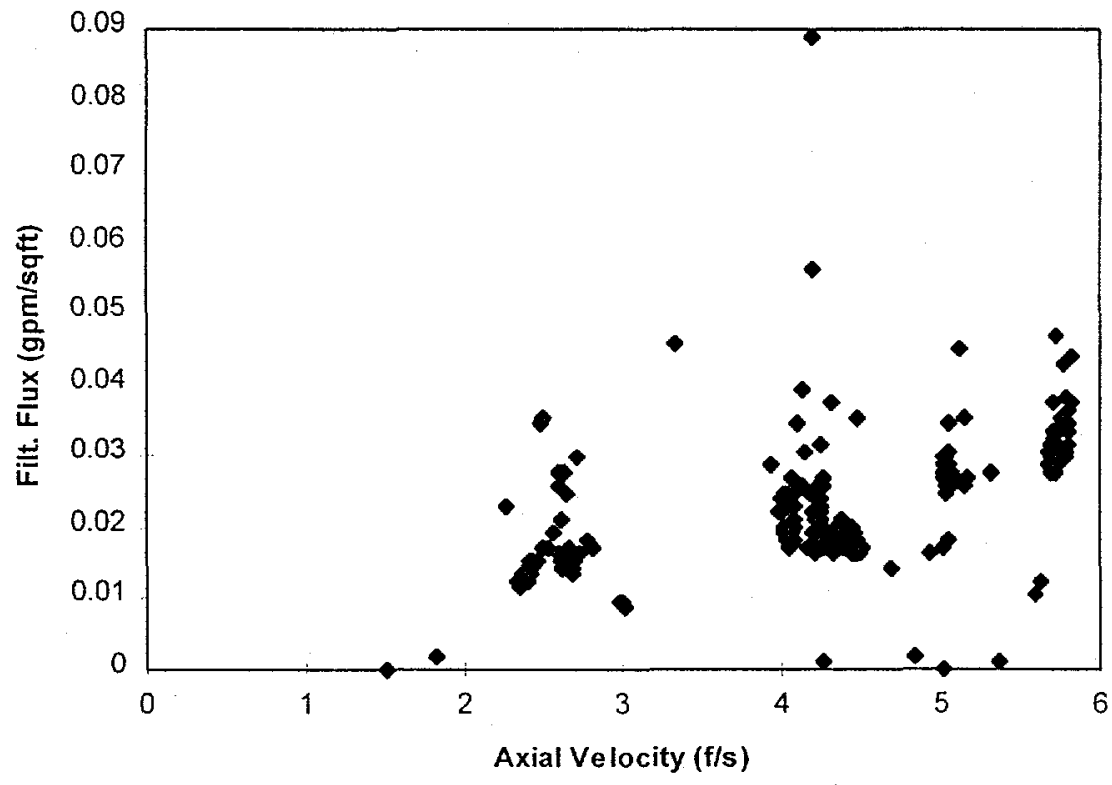


Figure 2 contains a plot of filtrate flux as a function of transmembrane pressure drop for the slurry without bentonite during filtration. Linear regression of this data reveals filtrate flux is independent of filter transmembrane differential pressure indicating that there is no solids deposition in the pores.

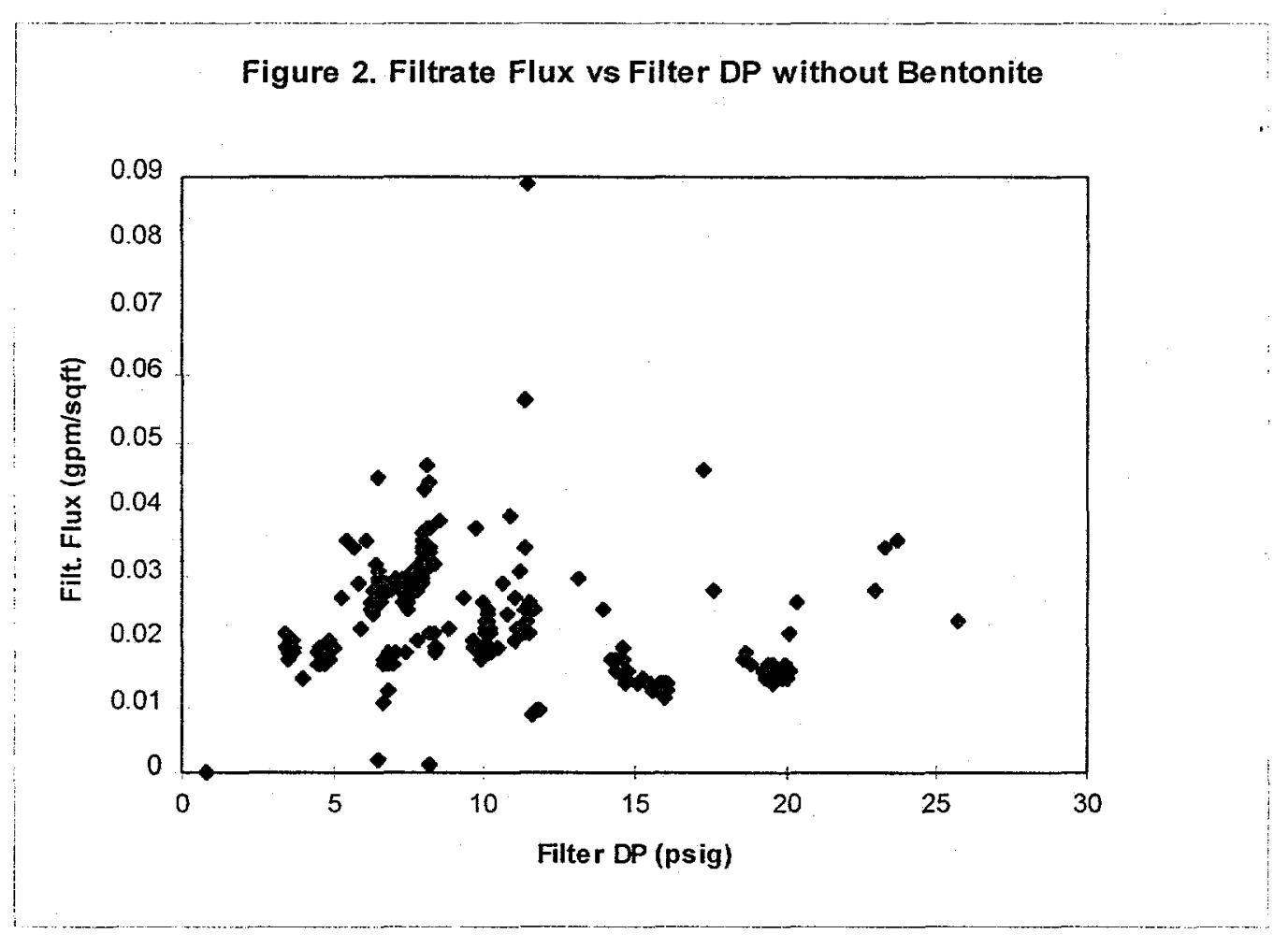


Figure 3 is a plot of the filtrate flux versus the time for the slurry without bentonite. Linear regression analysis of this data shows that filtrate production does not decrease significantly with time. This indicates filter fouling is not occurring during the filtration process.

The large increases or spikes of filtrate flux seen in this figure correspond to backpulsing of the filter.

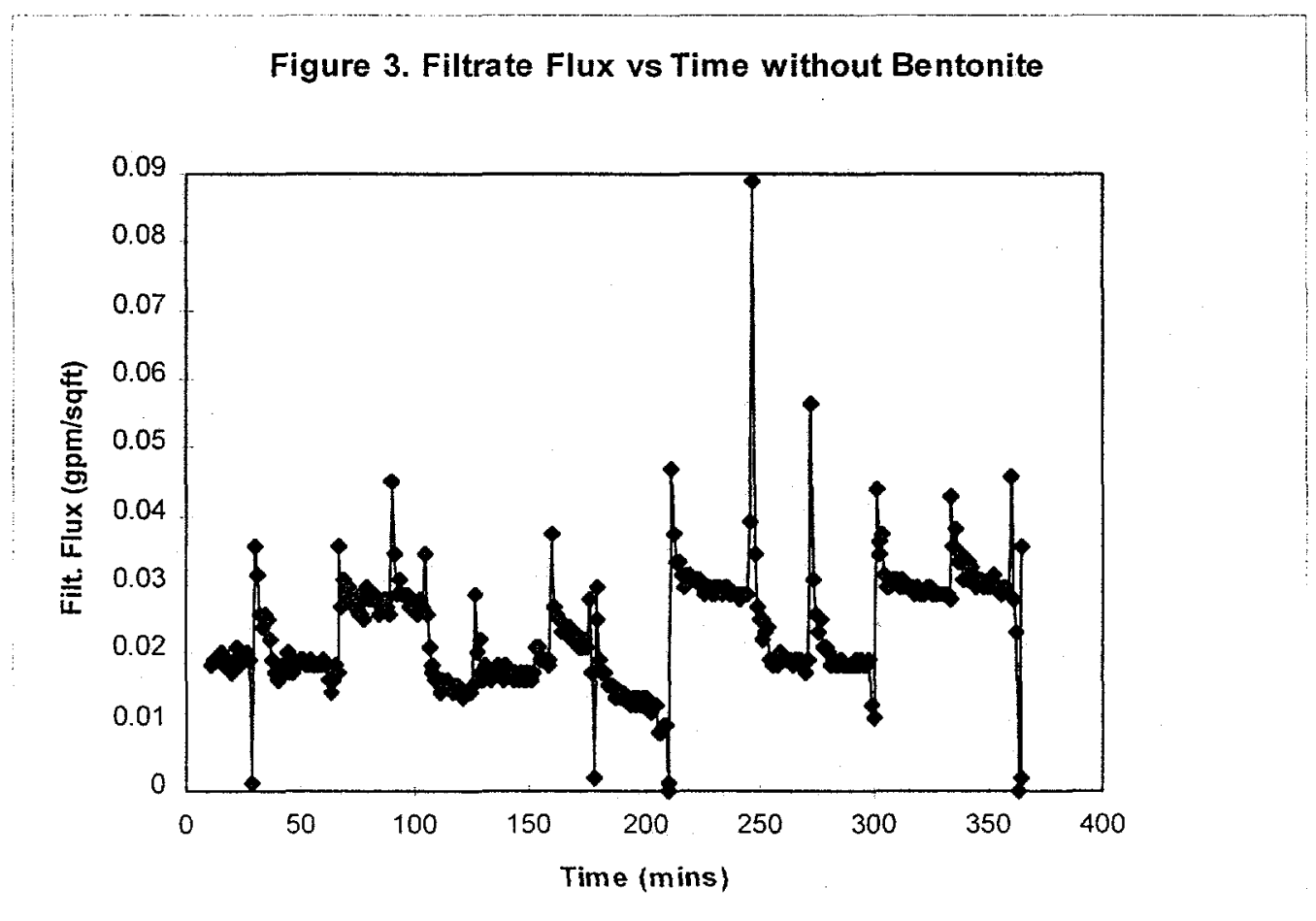


Figure 4 contains a plot of filtrate flux as a function of axial velocity for the slurry with Bentonite clay. Linear regression analysis of this data shows the filtrate flux is dependent on axial velocity indicating there is a surface filter cake formed. If a surface filter cake is formed usually the back transport of material from the surface of the filter cake is dictating filtrate flux.

The statistical analysis linear regression predicts the following dependence of filtrate flux on axial velocity of the slurry with Bentonite clay added.

$\mathrm{Q}=0.00697 \mathrm{~V}-3.25 \mathrm{e}-5$

where $\mathrm{Q}$ is the filtrate flux in $\left(\mathrm{gpm} / \mathrm{f}^{2}\right)$ and $\mathrm{V}$ is the axial velocity in $(\mathrm{f} / \mathrm{s})$

The $95 \%$ confidence interval for the axial velocity coefficient is $0.00885<\mathrm{c} 1<0.0051$

Figure 4. Filtrate Flux vs. Axial Velocity for Bentonite Slurry

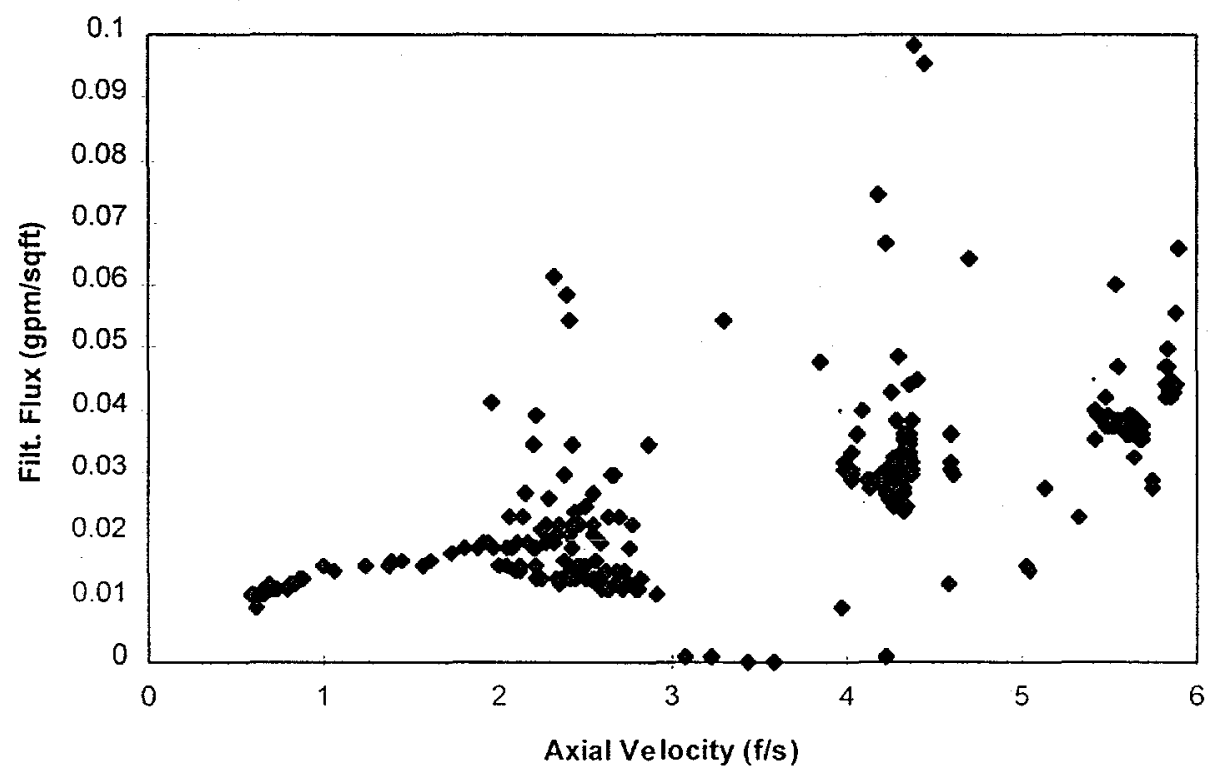


Figure 5 contains a plot of filtrate flux as a function of transmembrane pressure drop for the slurry with Bentonite. Linear regression analysis of this data predicts filtrate flux is dependent on filter transmembrane differential pressure indicating that there is deposition of solids in the pores of the filter.

The statistical model for filtrate flux dependence on transmembrane differential pressure was determined from linear regression analysis to be

$Q=-0.00119 D P+0.043269$

where $\mathrm{Q}$ is the filtrate flux in $\mathrm{gpm} / \mathrm{sqft}$ and $\mathrm{DP}$ is transmembrane differential pressure in psig. The $95 \%$ confidence interval for the transmembrane differential pressure coefficient is $-0.00138<\mathrm{c} 1<-0.001$

Figure 5. Filtrate Flux vs DP for Bentonite Slurry

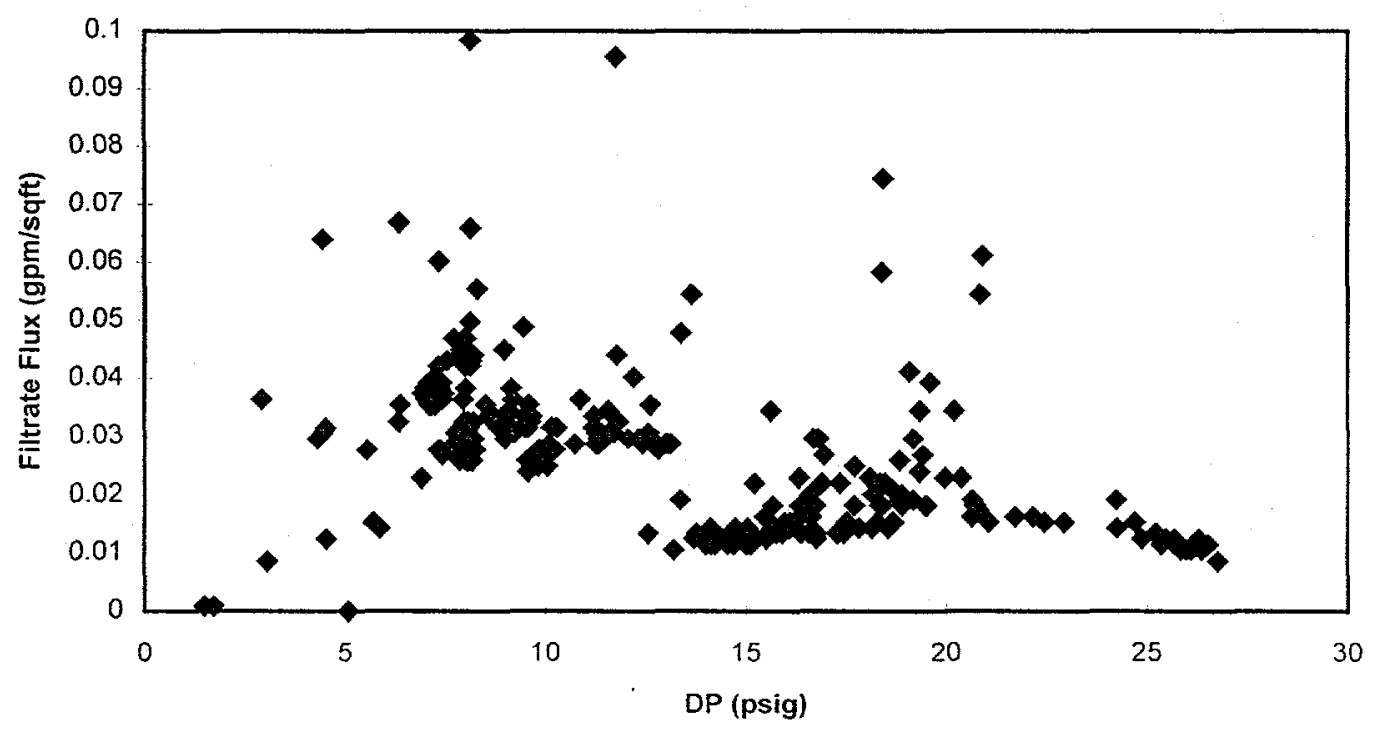


WSRC-TR-97-00354 R1

Page 14 of 20

Figure 6 is a plot of the filtrate flux versus time for the bentonite slurry. Linear regression analysis of this data predicts that filtrate production does not decrease significantly with time. If filtrate production is not dependent on time it would suggest filter fouling is not occurring as the bentonite slurry is filtered.

The large increases or spikes of filtrate flux seen in this figure correspond to backpulsing of the filter.

Figure 6. Filtrate Flux vs Time for Bentonite Slurry

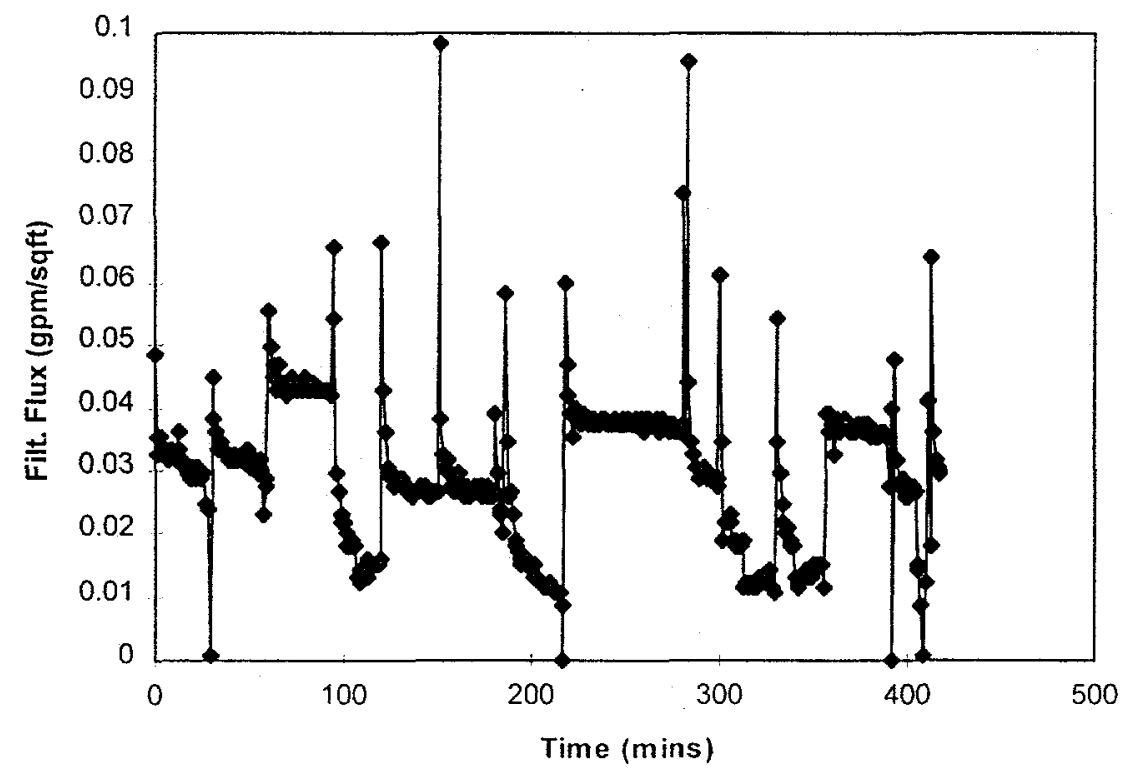


WSRC-TR-97-00354 R1

Page 15 of 20

Upon conclusion of the filter test the filters were cleaned. During the cleaning step, all the slurry was removed from the process vessel and process lines. These lines were then flushed three times in a once through pass filled with inhibited $(\mathrm{pH} \mathrm{10)}$ water. The process vessel was then filled with inhibited $(\mathrm{pH} 10)$ water that was recirculated for a period of 1 hour with backpulses every 10 minutes. The water was drained and $2 \mathrm{wt} \%$ $\mathrm{NaOH}$ solution was placed in the feed tank and recirculated with backpulses every 10 minutes for several hours. The $2 \mathrm{wt} \% \mathrm{NaOH}$ solution was drained and next a $2 \mathrm{wt} \%$ oxalic acid solution was added to the feed tank and recirculated with backpulses every 10 minutes for several hours.

These cleaning treatments were not sufficient to clean the Mott filter as evidenced by a low clean water flux. The cleaning method was modified by using $2 \mathrm{wt} \% \mathrm{HNO}_{3}$ solution followed by deionized water. This treatment was sufficient to obtain a flux $80 \%$ of the vendor literature for a clean water flux, which is the criteria for a clean filter (See Table 2 and Table 3).

Table 2 - Clean Water Flux Before Filtration

Mott Filter 1

$\begin{array}{llllll}\begin{array}{l}\text { Filter Inlet } \\ \text { Pressure } \\ \text { (psig) }\end{array} & \begin{array}{l}\text { Filter Outlet } \\ \text { Pressure } \\ \text { (psig) }\end{array} & \begin{array}{l}\text { Filtrate } \\ \text { Pressure } \\ (\text { psig) }\end{array} & \begin{array}{l}\text { Vendor Flux } \\ \text { Clean Flux } \\ \text { (Gal/hr) }\end{array} & \begin{array}{l}\text { Actual } \\ \text { Flux } \\ \text { (Gal/hr) }\end{array} & \text { \% Clean } \\ 10 & 11 & 5.5 & 25.5 & 22 & 86.3 \\ 20.5 & 21 & 12.4 & 35.5 & 32 & 90.1 \\ 30.5 & 31.5 & 16.9 & 40 & 36 & 90 \\ 40.5 & 41 & 22 & 48 & 41 & 85.4 \\ 36 & 36 & 18.3 & 44 & 38 & 86.4 \\ 25 & 26 & 17.1 & 39 & 36 & 92.3 \\ 15 & 17 & 9.8 & 31 & 28 & 90.3 \\ 39 & 40 & 19.6 & 48 & 39 & 81.3\end{array}$


WSRC-TR-97-00354 R1

Page 16 of 20

Mott Filter 2

$\begin{array}{llllll}\begin{array}{l}\text { Filter Inlet } \\ \begin{array}{l}\text { Pressure } \\ \text { (psig) }\end{array}\end{array} & \begin{array}{l}\text { Filter Outlet } \\ \text { Pressure } \\ \text { (psig) }\end{array} & \begin{array}{l}\text { Filtrate } \\ \text { Pressure } \\ \text { (psig) }\end{array} & \begin{array}{l}\text { Vendor Flux } \\ \text { Clean Flux } \\ \text { (Gal/hr) }\end{array} & \begin{array}{l}\text { Actual } \\ \text { Flux } \\ \text { (Gal/hr) }\end{array} & \text { \% Clean } \\ 9 & 10 & 6 & & & \\ 20 & 21 & 13 & 25.5 & 21 & 86.3 \\ 31 & 30.5 & 18 & 45.5 & 32 & 91.7 \\ 39 & 39 & 22.6 & 40 & 37 & 100 \\ 36 & 35 & 20.1 & 44 & 41 & 91.7 \\ 24 & 25 & 12.8 & 39 & 39 & 95.5 \\ 15 & 15 & 10.1 & 31 & 32 & 90.0 \\ 39.5 & 41.5 & 23.6 & 48 & 28 & 87.5 \\ & & & & 42 & 91.7\end{array}$

Table 3 - Clean Water Flux After Filtration and Cleaning with 2 wt \% HNO3

Mott Filter 1

$\begin{array}{llllll}\begin{array}{l}\text { Filter Inlet } \\ \begin{array}{l}\text { Pressure } \\ \text { (psig) }\end{array}\end{array} & \begin{array}{l}\text { Filter Outlet } \\ \text { Pressure } \\ \text { (psig) }\end{array} & \begin{array}{l}\text { Filtrate } \\ \text { Pressure } \\ \text { (psig) }\end{array} & \begin{array}{l}\text { Vendor Flux } \\ \text { Clean Flux } \\ \text { (Gal/hr) }\end{array} & \begin{array}{l}\text { Actual } \\ \text { Flux } \\ (\mathrm{Gal} / \mathrm{hr})\end{array} & \text { \% Clean } \\ 10 & 10 & 5 & & & \\ 20 & 23 & 14 & 25.5 & 21 & 82.4 \\ 30 & 33 & 19 & 35.5 & 33 & 92.9 \\ 40 & 44 & 27 & 40 & 39 & 97.5 \\ 35 & 36 & 22 & 48 & 44 & 91.7 \\ 25 & 27 & 16 & 44 & 40 & 90.9 \\ 15 & 16 & 9 & 39 & 35 & 89.7 \\ & & & 31 & 26 & 83.9\end{array}$


Mott Filter 2

$\begin{array}{llllll}\begin{array}{l}\text { Filter Inlet } \\ \text { Pressure } \\ \text { (psig) }\end{array} & \begin{array}{l}\text { Filter Outlet } \\ \text { Pressure } \\ \text { (psig) }\end{array} & \begin{array}{l}\text { Filtrate } \\ \text { Pressure } \\ \text { (psig) }\end{array} & \begin{array}{l}\text { Vendor Flux } \\ \text { Clean Flux } \\ \text { (Gal/hr) }\end{array} & \begin{array}{l}\text { Actual } \\ \text { Flux } \\ \text { (Gal/hr) }\end{array} & \text { \% Clean } \\ 10 & 10 & 5.3 & 25.5 & 26 & 84.6 \\ 20 & 20 & 12 & 35.5 & 36 & 83.3 \\ 30 & 30 & 18 & 40 & 40 & 95 \\ 40 & 43 & 27 & 48 & 48 & 91.7 \\ 35 & 35 & 22 & 44 & 44 & 90.9 \\ 25 & 25 & 15 & 39 & 40 & 85 \\ 15 & 15 & 9.5 & 31 & 32 & 84.4 \\ 40 & 43 & 27 & 48 & 48 & 91.7\end{array}$

Particle size distribution data were collected on the simulated waste samples. Particle size analyses were conducted using a Microtrac II, Series 7998 Particle Size Analyzer. The range of this instrument is 0.7 to 700 microns. Three columns of data are presented in Table 4: the particle diameter below which 10,50 , and 90 volume percent of the particles lie. For example, the $6.8 \mathrm{wt} \%$ Slurry no pumping sample had $10 \%$ of the sample particles less than 5.37 microns, $50 \%$ of the sample particles less than 20.65 microns, and $90 \%$ of the sample particles less than 41.25 microns.

Table 4 - Particle Size Data

\begin{tabular}{|c|c|c|c|}
\hline Sample Description & $10 \%$ (microns) & $\underline{50 \% \text { (microns) }}$ & $90 \%$ (microns) \\
\hline $\begin{array}{l}6.8 \text { wt } \% \text { Slurry } \\
\text { no pumping }\end{array}$ & 5.37 & 20.65 & 41.25 \\
\hline $\begin{array}{l}11.3 \mathrm{wt} \% \text { Slurry } \\
\text { no clay after pumping }\end{array}$ & 4.46 & 17.61 & 32.39 \\
\hline $\begin{array}{l}10.62 \text { wt } \% \text { Slurry } \\
\text { with clay after pumping }\end{array}$ & 2.26 & 14.93 & 30.2 \\
\hline
\end{tabular}

The results of the particle size analysis of slurry samples indicate marginal decreases in the particle size. 
Rheology of the different slurries was measured using a Rotational Viscometer at different points of the filtration study. The results are given in Table 5. Inspection of the rheology data in Table 5 shows that the viscosity gives relatively the same range of 16.4 to $36.0 \mathrm{cp}$. The rheology data for the different slurries exhibit the same behavior as a Newtonian fluid. The viscosity remains nearly the same before and after pumping, and with or without clay. Viscosity does not change because the particle size is not changing. This suggests that shearing is not occurring which makes particle size smaller causing a change in viscosity.

\section{Table 5 - Slurry Rheology Data}

Slurry

Description

6.8 wt $\%$, before Newtonian pumping

11.3 wt $\%$, after

pumping, no clay

$10.6 \mathrm{wt} \%$, after

pumping, with clay
Newtonian

Newtonian

Fluid

Model
16.4

26.0

NA

NA

Plastic

NA

36.0
NA

Yield

Stress (dynes $/ \mathrm{cm}^{2}$ )

NA

NA 


\section{Conclusions}

- Cross-flow filtration was proven to be an effective solid-liquid separation technology for simulant with and without Bentonite clay.

- Filter cake formation on the filter surface probably occurs for the slurry with clay because the filtrate flow is dependent on slurry axial velocity. Filter cake formation on the surface is thought to be the primary resistance to passage of filtrate through the filter when both slurry and bentonite are present.

- Filter cake formation on the surface does not appear to occur for the slurry without clay because the filtrate flow is independent of slurry axial yelocity. Back transport of rejected slurry particles and boundary layer interactions usually do not play a role in filter performance when there is no filter cake on the filter surface.

- The dependence of filtrate flow on transmembrane differential pressure for the slurry containing bentonite clay suggests that sub-surface fouling of the pores is occurring. The simulant not containing bentonite clay appears to be relatively insensitive to transmembrane pressure changes. Any dependence on the transmembrane pressure for the slurry without bentonite was probably not observable due to the relative narrow pressure range accessible with this equipment.

- Analyses proves that the particle size is slightly reduced during pumping with these slurries. Since the filtrate flow rate is independent of time for both simulants with and without bentonite clay filter fouling is not occurring. The majority of the filtrate flow rates of the slurries with and without bentonite are within the same range of .01 to .06 $\mathrm{gpm} / \mathrm{f}^{2}$.

- Filters can be cleaned (restored to $80 \%$ of the original clean water flux) using $2 \mathrm{wt} \%$ $\mathrm{HNO}_{3}$ solution cleaning but not with $2 \mathrm{wt} \% \mathrm{NaOH}$ or $2 \mathrm{wt} \%$ oxalic acid. 
WSRC-TR-97-00354 RI

Page 20 of 20

Acknowledgments

This work was done as part of the DOE Office of Science and Technology, Tanks Focus Area program (TTP SR-16WT-41); C.P. McGinnis, Pretreatment Technical Integration Manager; K. Gerdes, Office of Science and Technology Program Manager.

References

1. WSRC-TR-95-0337, "Evaluation and Ranking of the Tank Focus Area Solid Liquid Separation Needs (U)", D.J. McCabe, June 17,1995.

2. "Concentration of Melton Valley Storage Tank Surrogates with a Wiped Film Evaporator"; M.D. Boring, L.L. For, V.L. Fowler, and J.D. Hewitt, ORNL/TM-12768, August 1994.

3. WSRC-TR-95-0420, "Filter Performance Mechanisms", R.A. Peterson, C.A. Nash, October 1995.

$\underline{\text { Authors }}$
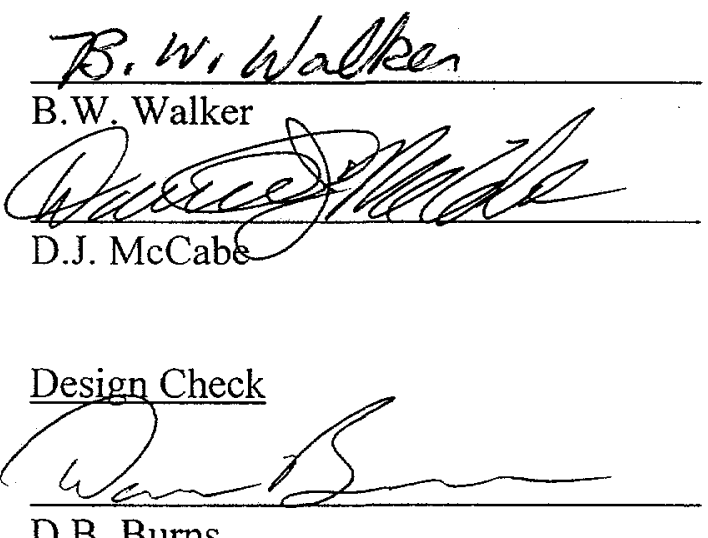

D.B. Burns
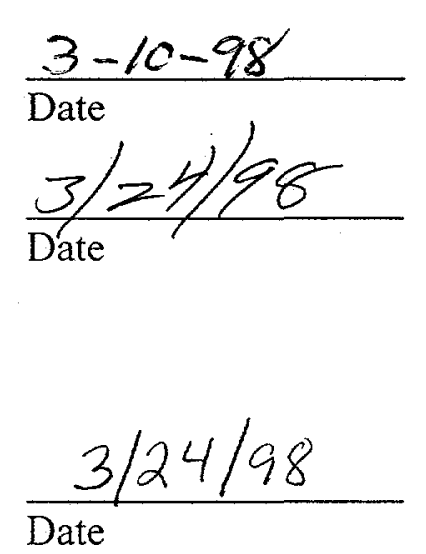

Level 3 Manager
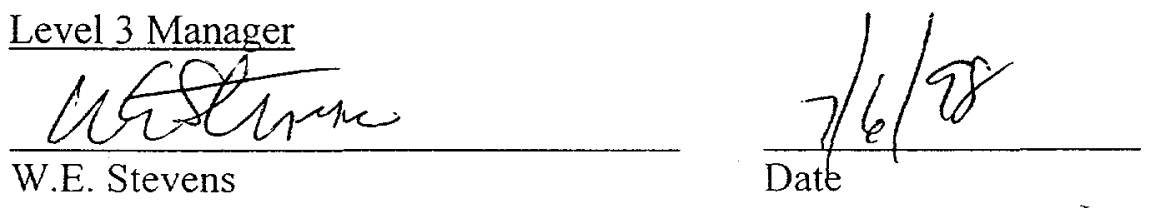